\title{
The novel arylindolylmaleimide PDA-66 displays pronounced antiproliferative effects in acute lymphoblastic leukemia cells
}

\author{
Christin Kretzschmar $^{1 \dagger}$, Catrin Roolf ${ }^{1 \dagger}$, Tina-Susann Langhammer ${ }^{1}$, Anett Sekora ${ }^{1}$, Anahit Pews-Davtyan ${ }^{2}$, \\ Matthias Beller ${ }^{2}$, Moritz J Frech ${ }^{3}$, Christian Eisenlöffel ${ }^{3}$, Arndt Rolfs ${ }^{3,4}$ and Christian Junghanss ${ }^{{ }^{*}}$
}

\begin{abstract}
Background: Prognosis of adult patients suffering from acute lymphoblastic leukemia (ALL) is still unsatisfactory. Targeted therapy via inhibition of deregulated signaling pathways appears to be a promising therapeutic option for the treatment of ALL. Herein, we evaluated the influence of a novel arylindolylmaleimide (PDA-66), a potential GSK3 $\beta$ inhibitor, on several ALL cell lines.

Methods: ALL cell lines (SEM, RS4;11, Jurkat and MOLT4) were exposed to different concentrations of PDA-66. Subsequently, proliferation, metabolic activity, apoptosis and necrosis, cell cycle distribution and protein expression of Wnt and PI3K/Akt signaling pathways were analyzed at different time points.

Results: PDA-66 inhibited the proliferation of ALL cells significantly by reduction of metabolic activity. The $72 \mathrm{~h}$ IC50 values ranged between 0.41 to $1.28 \mu$ M PDA-66. Additionally, caspase activated induction of apoptosis could be detected in the analyzed cell lines. PDA-66 influenced the cell cycle distribution of ALL cell lines differently. While RS4;11 and MOLT4 cells were found to be arrested in G2 phase, SEM cells showed an increased cell cycle in G0/1 phase.
\end{abstract}

Conclusion: PDA-66 displays significant antileukemic activity in ALL cells and classifies as candidate for further evaluation as a potential drug in targeted therapy of ALL.

Keywords: Arylindolylmaleimide, Glycogen Synthase Kinase 3ß, Acute lymphoblastic leukemia, Apoptosis, Enzyme inhibitors

\section{Background}

Acute lymphoblastic leukemia (ALL) is characterized by a poor prognosis in adult patients with a general survival rate of 27 to $54 \%$ [1]. In recent years targeted therapeutic approaches such as Imatinib or Rituximab have been developed and implemented successfully in the treatment [2-4]. However, despite of these implementations the prognosis of adult patients remains poor indicating the need for further research in order to identify and evaluate new potential drugs targeting deregulated signaling pathways.

\footnotetext{
* Correspondence: christian.junghanss@med.uni-rostock.de

${ }^{\dagger}$ Equal contributors

'Department of Hematology/Oncology/Palliative Medicine, Division of Medicine, University of Rostock, Ernst-Heydemann-Str. 6, Rostock 18057, Germany

Full list of author information is available at the end of the article
}

Arylindolylmaleimides are a group of synthetic molecules characterized by the conjunction of a maleimide compound with a bicyclic indole ring and a further aromatic structure. PDA-66 is an analogue of the arylindolylmaleimide SB-216763 and was newly synthesized as described by Pews-Davtyan et al. [5]. Both compounds possess similar structural features, but differ in their substitution pattern (Figure 1). In comparison to SB216763 , in PDA-66 the indolyl group is characterized by an unprotected 2-methylindole unit, while the maleimide group is methylated. Notably, the 2,4-dichloro substitution pattern is replaced with 4-acetyl group. Concerning functional activity SB-216763 was shown to inhibit the enzyme activity of Glycogen Synthase Kinase $3 \beta$ (GSK3 $\beta$ ) by $96 \%$ at a concentration of $10 \mu \mathrm{M}$ (IC50: $34.3 \mathrm{nM})$ in an ATP competitive manner [6] leading to

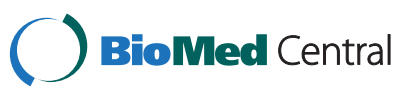




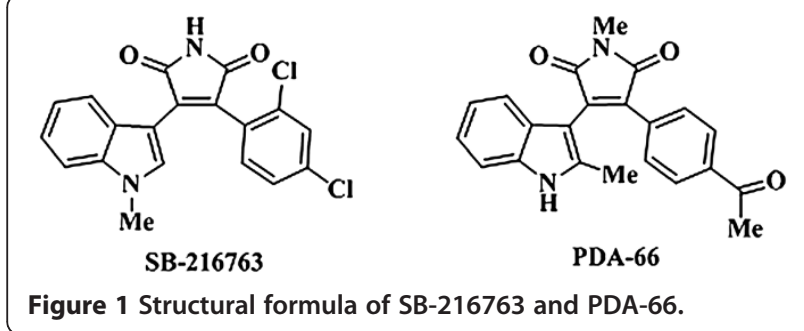

the hypothesis that potential effects of PDA-66 might also be mediated by GSK3 $\beta$ inhibition.

GSK3 $\beta$ is a highly activated serine/threonine kinase in resting cells with normal metabolism [7]. Besides its influence on the glycogen synthesis GSK3 $\beta$ is involved in $\mathrm{Wnt} / \beta$-catenin and Phosphatidylinositole 3 kinase (PI3K)/Akt signaling antagonizing cell growth and cell cycle progression in both pathways. However, inhibition of GSK3 $\beta$ led to decreased cell growth and increased apoptosis in different tumor cell lines as glioblastoma cells [8], gastrointestinal cancer cells [9,10], ovarian cancer cells [11], medullary thyroid cancer cells [12], pancreatic cancer cells [13] and primary pediatric ALL cells [14]. Joint previous analyses published by Eisenlöffel et al. [15] investigated the influence of PDA-66 in human neuronal progenitor cells (hNPCs) and revealed an inhibitory effect on proliferation and an increased rate of apoptosis. Furthermore, an antiproliferative impact on human lung cancer and glioblastoma cell lines was detected [15].

In this study, we analyzed the biological effects of PDA66 on B- and T-ALL cell lines and determined the influence on kinase activity of human recombinant GSK3 3 . Our results show an inhibitory effect on the proliferation and metabolic activity of ALL cells accompanied by an increase in apoptosis and necrosis rates. Furthermore, a minor effect on GSK3 $\beta$ activity could be demonstrated which was not as pronounced as caused by SB-216763.

\section{Methods}

\section{Inhibitors}

PDA-66 was synthesized at the Leibniz Institute for Catalysis (Rostock, Germany) and kindly provided by the Albrecht-Kossel-Institute (Rostock, Germany). SB-216763 was purchased from Sigma (Taufkirchen, Germany). Chemical structures of both substances are displayed in Figure 1. The substances were dissolved in dimethyl sulfoxide (DMSO). The stock solutions $(10 \mathrm{mM})$ were stored at $-20^{\circ} \mathrm{C}$. For experimental use the drugs were freshly prepared from stock solution.

\section{Cell lines}

The human B-ALL cell lines SEM, RS4;11 and the TALL cell lines Jurkat and MOLT4 were purchased from DSMZ (Braunschweig, Germany) and cultured according to manufacturer's protocol. The corresponding medium was supplemented with $10 \%$ heat-inactivated fetal bovine serum (PAA, Pasching, Austria) and 1\% penicillin and streptomycin (Biochrom AG, Berlin, Germany). The MOLT4 cells were cultured with medium supplemented with $20 \%$ heat-inactivated fetal bovine serum. All cells were maintained at $37^{\circ} \mathrm{C}$ in $5 \% \mathrm{CO}_{2}$.

\section{Treatment of ALL cell lines with PDA-66}

Cells $\left(5 \times 10^{5} /\right.$ well) were seeded in 24 well plates (Nunc, Langenselbold, Germany) and incubated for up to $72 \mathrm{~h}$ with different concentrations of PDA-66 $(0.1-10 \mu \mathrm{M})$. Treated cells were harvested after 4, 24, 48 and $72 \mathrm{~h}$ and used for further analyses. Control cells were cultured in medium containing the same concentration of DMSO as the cells treated with the highest dose of PDA-66.

\section{Proliferation studies}

Cell counts were determined by trypan blue staining. Metabolic activity was analyzed by tetrazolium compound WST-1 (Roche, Mannheim, Germany). In brief, triplicates of cells $\left(5 \times 10^{4} / 150 \mu \mathrm{l}\right)$ were seeded in 96 well plates, treated with different concentrations of PDA-66 and incubated with $15 \mu \mathrm{l}$ WST-1 for up to $4 \mathrm{~h}$. The mitochondrial dehydrogenases reduce WST-1 to soluble formazan and cause a change of color correlating with the amount of metabolically active cells. Absorbance at $450 \mathrm{~nm}$ and a reference wavelength at $620 \mathrm{~nm}$ were determined by an ELISA Reader (Anthos, Krefeld, Germany). The absorbance of culture medium with supplemented WST-1 in the absence of cells was used as background control.

\section{May-Grünwald Giemsa staining}

After treatment with $1 \mu \mathrm{M}$ PDA-66 glass slides were prepared with $3 \times 10^{4}$ cells with Cytospin 3 centrifuge (Shandon, Frankfurt/Main, Germany). Briefly, slides were incubated $6 \mathrm{~min}$ in May-Grünwald solution (Merck, Darmstadt, Germany), washed with tap water, incubated $20 \mathrm{~min}$ in Giemsa solution (Merck, Darmstadt, Germany), and washed in tap water again. To evaluate morphological changes of the cells slides were analyzed by Nikon Eclipse E 600 light microscope and imaged with NIS Elements software (Nikon, Düsseldorf, Germany).

\section{Analyses of apoptosis and necrosis}

Apoptosis and necrosis were analyzed by staining the cells with Annexin V FITC (BD Biosciences, Heidelberg, Germany) and Propidium iodide (PI) (Sigma Aldrich, St. Louis, USA). Results were assessed by flow cytometry. Briefly, $5 \times 10^{5}$ cells were harvested and washed twice $\left(180 \mathrm{~g}, 10 \mathrm{~min}, 4^{\circ} \mathrm{C}\right.$ ) with PBS. After resuspending the cells in $100 \mu \mathrm{l}$ of binding buffer (1×) $4 \mu \mathrm{l}$ of Annexin V FITC was added and incubated for $15 \mathrm{~min}$ at room 
temperature, respectively. Following addition of $400 \mu \mathrm{l}$ binding buffer for a final volume of $500 \mu \mathrm{l}$ the cells were stained with PI $(0.6 \mu \mathrm{g} / \mathrm{ml})$ immediately before measurement. Unstained and single stained cells were included in each experiment as controls. Measurements were performed using FACSCalibur (Becton, Dickinson and Company, Heidelberg, Germany) and data analyzed by CellQuest software (Becton, Dickinson and Company, Heidelberg, Germany).

\section{Cell cycle analysis}

After treatment cells were harvested and washed twice in PBS. Cells were fixed with $70 \%$ ethanol and incubated with $1 \mathrm{mg} / \mathrm{ml}$ Ribonuclease A (Sigma-Aldrich, St. Louis, USA) for $30 \mathrm{~min}$ at $37^{\circ} \mathrm{C}$. After washing the cells twice in PBS, they were stained with PI $(50 \mu \mathrm{g} / \mathrm{ml})$ and DNA content was determined by flow cytometry.

\section{Western blot}

Protein extraction and western blot was performed as described previously [16]. Following antibodies were used: rabbit anti-cleaved caspase 3 (5A1E), rabbit anti-caspase 3 (polyclonal), rabbit anti-cleaved PARP (D64E10), rabbit anti-PARP (polyclonal), rabbit anti-cleaved caspase 7 (polyclonal), rabbit anti-caspase 7 (polyclonal), rabbit antipAktThr308 (polyclonal), rabbit anti-pAktSer473 (polyclonal), rabbit anti-Akt (polyclonal), rabbit anti- $\beta$-catenin (6B3), rabbit anti-pGSK3ßSer9 (5B3), rabbit anti-GSK3 $\beta$ (27C10), rabbit anti-p4EBP-1Ser65 (174A9) and rabbit anti-4EBP-1 (polyclonal) (all Cell Signaling, Frankfurt/ Main, Germany). Blots were incubated with mouse antiGAPDH antibody (Invitrogen, Carlsbad, USA) as loading control.

\section{Kinase activity assay}

The kinase activity assay was performed as previously described [17]. Briefly, $20 \mathrm{ng}$ of recombinant human GSK3 $\beta$ (Biomol, Hamburg, Germany) were incubated with the substrate phospho glycogen synthase peptide 2 (pGS2, $25 \mu \mathrm{M})$ (Millipore, Billerica, USA), ATP $(1 \mu \mathrm{M})$ (Cell Signaling, Frankfurt am Main, Germany) and different concentrations of PDA-66 and SB-216763 for $30 \mathrm{~min}$ at $30^{\circ} \mathrm{C}$. After addition of Kinase-Glo (Promega, Mannheim, Germany) and $10 \mathrm{~min}$ of incubation at room temperature the luminescence signal was measured with a Glomax 96 microplate reader (Promega).

\section{Statistical analysis}

Results within each experiment were described using mean \pm standard deviation. Significance between control and treated cells was calculated using Student's t-test. A p-value $<0.05$ was considered to be significant. The IC50 values of PDA-66 where determined with SPSS (Version 15) software via probit analysis.

\section{Results}

PDA-66 inhibits proliferation and metabolic activity of ALL cells

The influence of PDA-66 on proliferation and metabolic activity in ALL cell lines SEM, RS4;11, Jurkat and MOLT4 was analyzed by incubation with different concentrations of the drug ranging from $0.1 \mu \mathrm{M}$ to $10 \mu \mathrm{M}$ for 48 and $72 \mathrm{~h}$, respectively (Figure 2). After $48 \mathrm{~h}$ incubation an inhibition of proliferation could be observed (Figure 2A), which was even more distinct after $72 \mathrm{~h}$ (Figure 2B). All cell lines showed a significant dose dependent inhibition of proliferation starting at a concentration of $0.5 \mu \mathrm{M}$ PDA-66.

Likewise proliferation, metabolic activity decreased with increasing concentrations of PDA-66. After $72 \mathrm{~h}$ of incubation the metabolic activity was significantly dose dependent reduced in all cell lines starting at a concentration of $0.5 \mu \mathrm{M}$ PDA-66 (Figure 2D). At this concentration the metabolic activity decreased to $35.7 \pm 8.3 \%$ in $\mathrm{SEM}$, to $33.3 \pm 4.4 \%$ in $\mathrm{RS} 4 ; 11$, to $66.7 \pm 8 \%$ in Jurkat and to $35.5 \pm 17 \%$ in MOLT4 cells compared to control cells treated with DMSO $(=100 \%)$. Furthermore, in WST-1 assay the IC50 for PDA-66 in all four cell lines where determined (Table 1). The IC50 values ranged from $0.41 \mu \mathrm{M}$ in SEM cells to $1.28 \mu \mathrm{M}$ in Jurkat cells after $72 \mathrm{~h}$ of incubation.

The incubation of ALL cell lines with higher dosages of PDA-66 (0.5 $\mu \mathrm{M}$ or more) led to a decrease in cell numbers below the amount of seeded cells $\left(5 \times 10^{5}\right)$. This result indicates besides an inhibition of cell proliferation also an induction of cell death.

\section{PDA-66 influences morphology as well as cell cycle progression and induces apoptosis}

To evaluate possible morphological changes cells were treated with $1 \mu \mathrm{M}$ of PDA-66 for $48 \mathrm{~h}$ and analyzed by light microscopy. All four cell lines showed similar changes in morphology after PDA-66 treatment compared to DMSO treated control cells. Exemplarily, effects in SEM and Jurkat cells are shown in Figure 3. In contrast to DMSO treated control cells the incubation of $1 \mu \mathrm{M}$ PDA-66 led to condensation of chromatin in the nucleus, karyorrhexis and an increasing amount of vacuoles and cell debris after $48 \mathrm{~h}$ of treatment. Condensated chromatin points to an induction of apoptosis or cell cycle arrest in the analyzed cell lines.

Cell cycle analysis was performed by PI staining and flow cytometrical measurement. The treatment with PDA-66 for $48 \mathrm{~h}$ influenced the four cell lines in different manner (Figure 4). SEM cells showed a significant increase in the amount of cells in G0/G1 after incubation with $0.5 \mu \mathrm{M}$ (DMSO control: $62.8 \pm 2.8 \%$; $0.5 \mu \mathrm{M}$ PDA-66: $69.3 \pm 2.7 \%$ ) whereas $1 \mu \mathrm{M}$ did not affect the cell cycle significantly. RS4;11 and MOLT4 cells were 


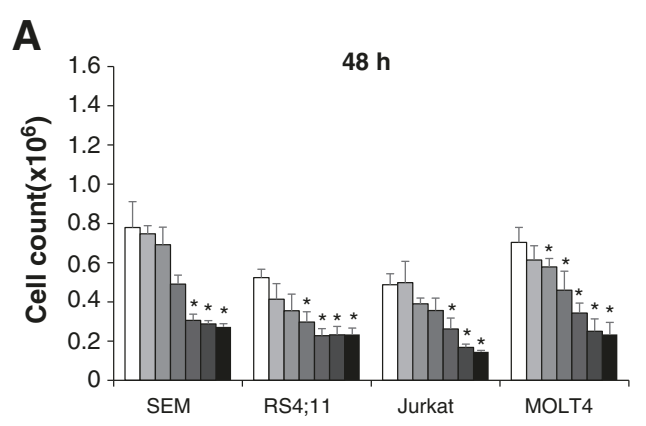

\section{C}

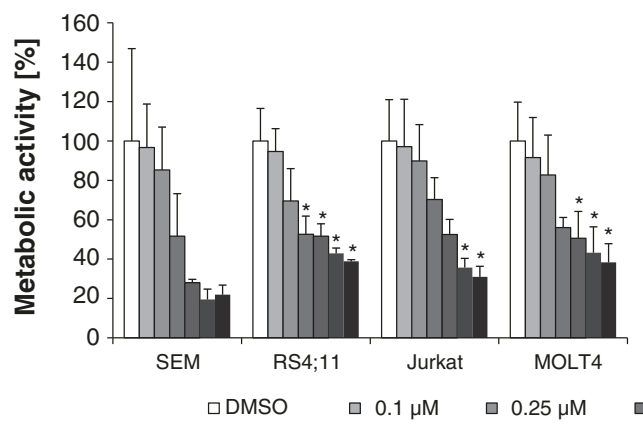

B

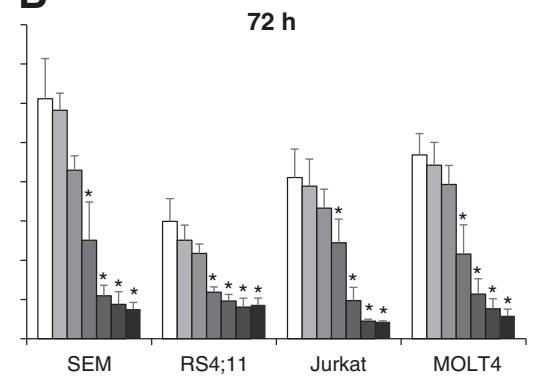

D

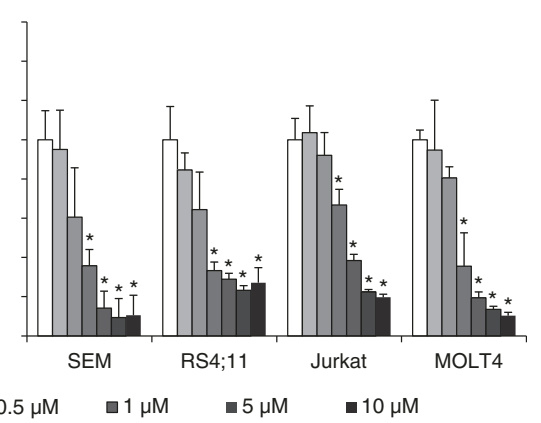

Figure 2 Treatment with PDA-66 inhibits cell proliferation and metabolic activity. SEM, RS4;11, Jurkat and MOLT4 cells were incubated with different concentrations of PDA-66. Metabolic activity was determined using WST-1 assay. The results of optical density measurement were expressed as a percentage of the DMSO treated control cells. The two upper diagrams show the results of cell count after PDA-66 treatment after $48 \mathrm{~h} \mathrm{(A)} \mathrm{and} 72 \mathrm{~h}$ (B). The lower diagrams display the influence of PDA-66 on the metabolic activity, respectively (C, D). The proliferation and metabolic activity of all cell lines was suppressed significantly at higher concentrations. Results are displayed as the mean + SD of three independent experiments. *Significant treatment effect vs. DMSO control, $a=0.05$.

characterized by a significant G2 arrest after treatment with $1 \mu$ M PDA-66. The amount of RS4;11 and MOLT4 cells in G2 phase increased from $20.1 \pm 3.9 \%$ and $21.9 \pm 4.9 \%$ after incubation with DMSO to $42.1 \pm 4.4 \%$ and $41.0 \pm 5.8 \%$ after $1 \mu \mathrm{M}$ PDA-66 treatment. This was associated with a significant decrease in G0/G1 phase (RS4;11 and MOLT4: $65.7 \pm$ $2.1 \%$ and $63.7 \pm 6.6 \%$ in control; $47.3 \pm 2.7 \%$ and $45.0 \pm$ $7.3 \%$ after treatment with $1 \mu \mathrm{M}$ PDA-66). On the other hand lower concentrations led to significant increase of cells in G0/G1 phase. Jurkat cells showed a significant decrease in G0/G1 phase (from $60.0 \pm 3.7 \%$ in control to 47.3 $\pm 4.3 \%$ with PDA-66) and an increase in $S$ phase (from $14.6 \pm 1.5 \%$ in control to $20.0 \pm 1.1 \%$ with PDA-66) after incubation with $1 \mu \mathrm{M}$ PDA-66. The analyses of cell cycle after longer incubation intervals interfered with high rates of apoptosis and necrosis (data not shown).

Table 1 IC50 values of PDA-66 in WST-1 assay

\begin{tabular}{|c|c|c|}
\hline & \multicolumn{2}{|c|}{$\mathrm{IC} 50[\mu \mathrm{M}]$} \\
\hline & $48 \mathrm{~h}$ & $72 \mathrm{~h}$ \\
\hline SEM & 0.85 & 0.41 \\
\hline RS4;11 & 2.14 & 0.74 \\
\hline Jurkat & 2.32 & 1.28 \\
\hline MOLT4 & 2.41 & 0.52 \\
\hline
\end{tabular}

The effect of PDA-66 on apoptosis and necrosis rates was determined by flow cytometric analysis after 48 and $72 \mathrm{~h}$ of incubation and further analysed by western blot after 24 and $48 \mathrm{~h}$, respectively (Figure 5). After $48 \mathrm{~h}$ of incubation all PDA-66 treated cell lines showed a significant increase in apoptosis compared to control cells (SEM: $2.1 \pm 0.9 \%$ to $10.5 \pm 1.3 \%$; RS4;11: $2.5 \pm 0.7 \%$ to $7.4 \pm 1.1 \%$; Jurkat: $3.8 \pm 0.6 \%$ to $8.3 \pm 1.9 \%$; MOLT4: $3.7 \pm 1.2 \%$ to $16.3 \pm 5.1 \%)$. After $72 \mathrm{~h}$ a similar tendency could be observed, but only deviations in SEM and MOLT4 cells where significant (SEM: $1.3 \pm$ $0.4 \%$ to $5.6 \pm 1.6 \%$; RS4;11: $2.1 \pm 0.9 \%$ to $6.4 \pm 3.6 \%$; Jurkat: $4.7 \pm 1.9 \%$ to $6.1 \pm 0.7 \%$; MOLT4: $4.9 \pm 1.9 \%$ to $20.1 \pm 6.6 \%)$.

All cells showed a non significant increase in necrosis after 48 and $72 \mathrm{~h}$ incubation with $1 \mu \mathrm{M}$ PDA-66. After $72 \mathrm{~h}$ incubation necrosis rate rose in SEM cells from 3.1 $\pm 1.6 \%$ to $27.8 \pm 5.81 \%$, in RS4; 11 cells from $6.1 \pm 0.8 \%$ to $26.5 \pm 10.2 \%$, in Jurkat cells from $5.7 \pm 3.5 \%$ to $28.0 \pm$ $13.4 \%$ and in MOLT4 cells from $11.7 \pm 3.6 \%$ to $46.7 \pm$ $15.6 \%$ (Figure $5 \mathrm{~A}$ ). Analysis via western blot showed an apoptosis induction in all cell lines. Treatment with PDA-66 induced cleavage of caspases 3 and 7 and PARP $48 \mathrm{~h}$ after addition of PDA-66. In Figure 5B results of SEM cells are displayed exemplarily. 


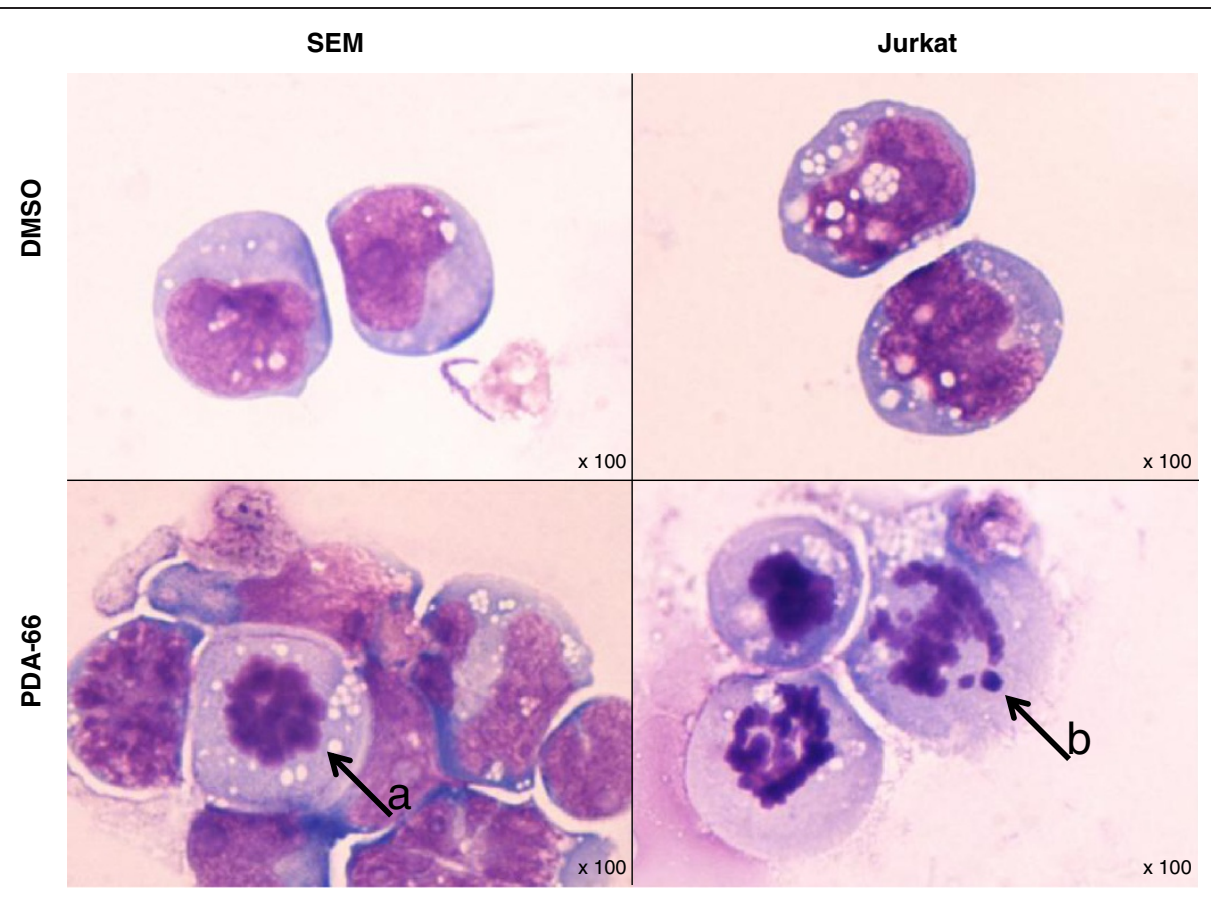

Figure 3 Light microscopy reveals karyorrhectic morphology after PDA-66 treatment in SEM and Jurkat cells. Cytospins of SEM and Jurkat cells were stained with Pappenheim method after $48 \mathrm{~h}$ incubation with $1 \mu \mathrm{M}$ PDA-66 and DMSO, respectively. Representative pictures are displayed. The upper pictures show SEM and Jurkat cells after DMSO treatment, the lower ones show PDA-66 treated cells. After treatment with PDA-66 an increased amount of cells with chromatin condensation (black arrow a) and karyorrhexis (black arrow b) could be observed along with more cell debris.

PDA-66 influences protein expression of 4EBP-1, but not $\beta$-catenin

In order to characterize the effects of PDA-66 on PI3K/ Akt and $\mathrm{Wnt} / \beta$-catenin pathways we performed western blot analysis. The time points of western blot analysis were shifted to 4 and $24 \mathrm{~h}$ as effects on protein level are expected to be detectable earlier compared to the effects on the whole cell. The incubation with PDA-66 showed no detectable influence on the expression of $\beta$-catenin, total GSK3 $\beta$ and total Akt at both time points
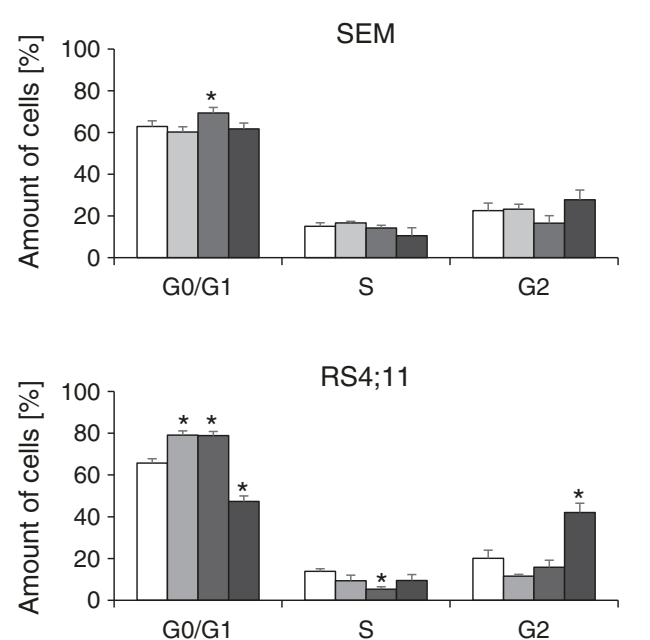

RS4;11

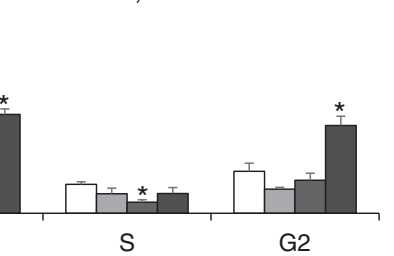

口DMSO

口 $0.25 \mu \mathrm{M}$
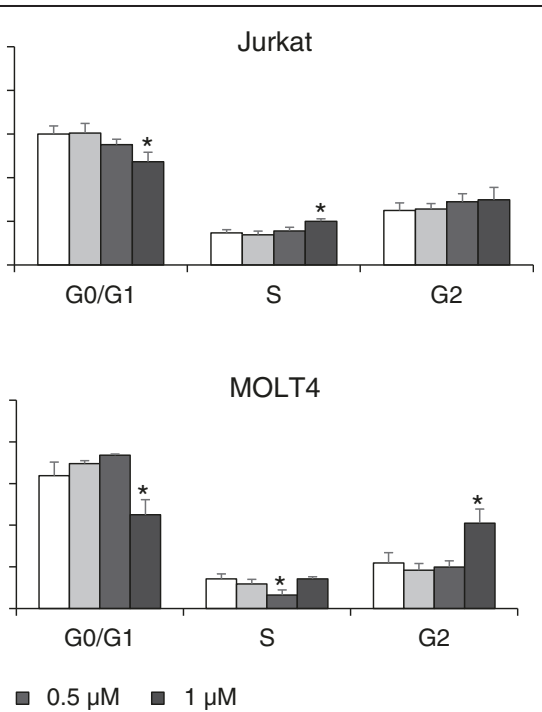

Figure 4 PDA-66 leads to cell cycle arrest in G2 phase in RS4;11 and MOLT4 cells. ALL cell lines were incubated for 48 h with PDA-66 and cell cycle distribution was determined using Propidium iodide staining. On the left side the amount of cells in the different phases of cell cycle is shown for the two B-ALL cell lines SEM and RS4;11. On the right side the results for the T-ALL cell lines Jurkat and MOLT4 are displayed, respectively. G2 arrest could be detected in RS4;11 and MOLT4 cells. Treatment of Jurkat cells induced a decrease of cells in G0/G1 phase in favor of cells in S phase. Results are displayed as the mean +SD of three independent experiments. *Significant treatment effect vs. DMSO control, $a=0.05$. 


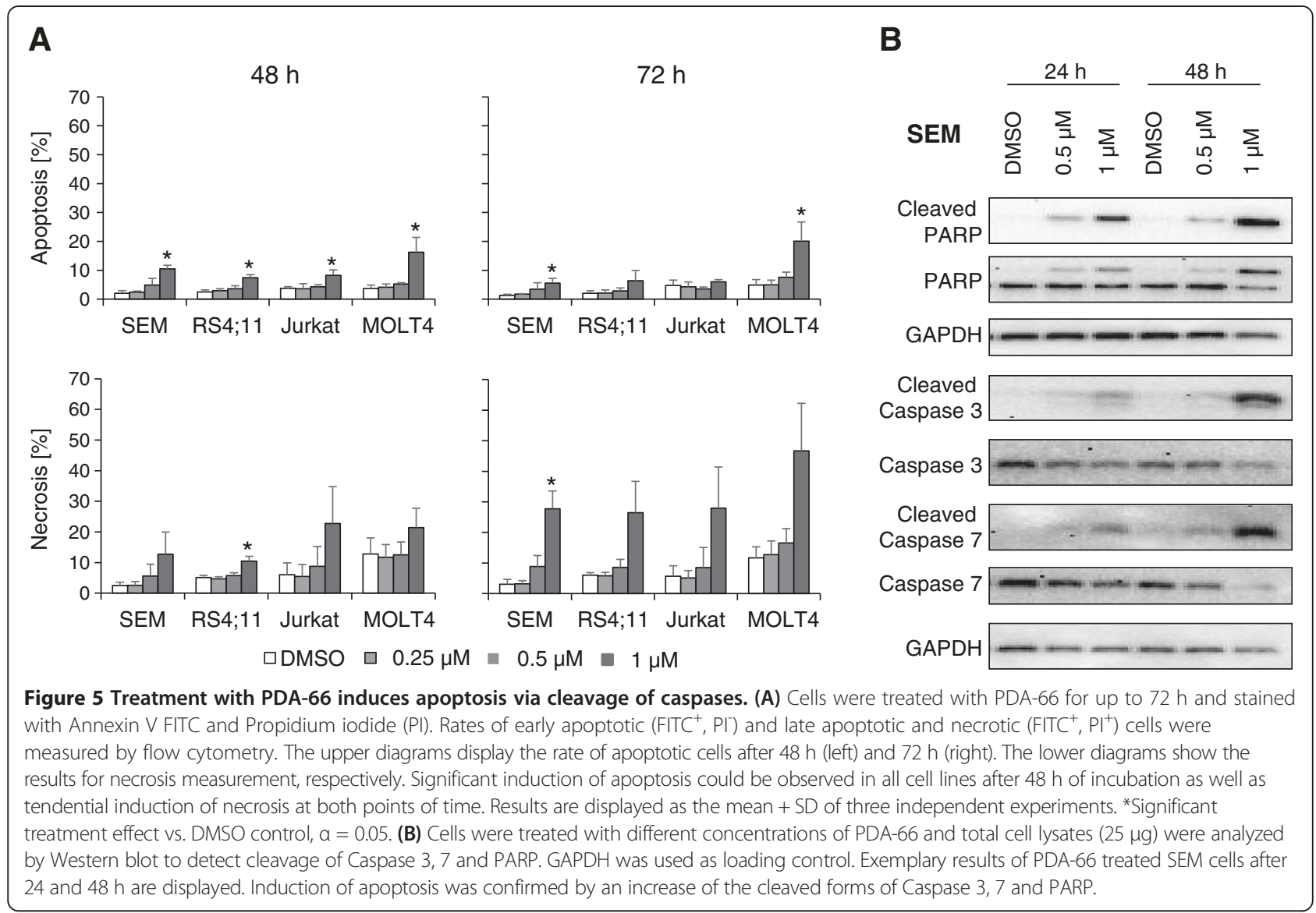

(Figure 6A). However, an increase of pAktThr308 could be detected in SEM cells after an incubation of $24 \mathrm{~h}$, though not accompanied by an increase of pAktSer 473 . Furthermore, in SEM cells a decrease of pGSK3 $\beta$ Ser9 was observed after $4 \mathrm{~h}$. However, no influence on the total form of $\beta$-catenin was detectable. Nevertheless, there was an influence of PDA-66 on the expression of 4EBP-1 and p4EBP-1Ser65. SEM, RS4;11 and Jurkat cells showed a decrease of the phosphorylated as well as the total form of 4EBP-1 after an incubation of 4 and $24 \mathrm{~h}$. In contrast, MOLT4 cells displayed an increase of the phosphorylated form at these points of time (Figure 6B).

\section{PDA-66 does not inhibit kinase activity of recombinant GSK3 $\beta$ as distinct as SB-216763}

The effect of PDA-66 on the GSK3 $\beta$ enzyme activity was determined by incubation with the specific substrate pGS2, PDA-66 or SB-216763 and ATP. The following addition of Kinase-Glo reagent converts the remaining ATP into a luminescence signal which correlates with enzyme inhibition. SB-216763 demonstrated a stable inhibition of GSK3 $\beta$ at concentrations from 0.1 to $5 \mu \mathrm{M}$ which was statistically significant at $5 \mu \mathrm{M}$ (Figure 7). Compared to this PDA-66 showed a less pronounced inhibition of enzyme activity at concentration from 0.1 to $1 \mu \mathrm{M}$ which were not significant.

\section{Discussion}

The prognosis of ALL in adult patients is still poor and requires further research for new therapeutic approaches. In this study we could demonstrate for the first time a pronounced antiproliferative effect of the novel arylindolylmaleimide PDA-66 on different B and T ALL cell lines. We investigated the influence of PDA-66 on ALL cells in respect of proliferation, metabolic activity, morphology, apoptosis, cell cycle arrest, and activation of PI3K/Akt and Wnt/ $\beta$-catenin signaling pathways. Furthermore, the effect on kinase activity of GSK3 $\beta$ was determined.

PDA-66 was recently synthesized and described as an analogue to SB-216763, which is a known GSK3 $\beta$ inhibitor [6]. The inhibition of this kinase has been extensively examined in various neoplastic cells types and demonstrated an attenuated proliferation in malignant cells [9-14]. Investigating the influence of PDA-66 on the enzyme activity of human recombinant GSK3 $\beta$ we found a minor inhibition in vitro which was much less distinct and not significant compared to our results obtained with SB-216763. While the basic molecular structure of SB-216763 and PDA-66 is the same, both compounds differ in their substitution patterns. In comparison to SB-216763, PDA-66 is characterized by an unprotected 


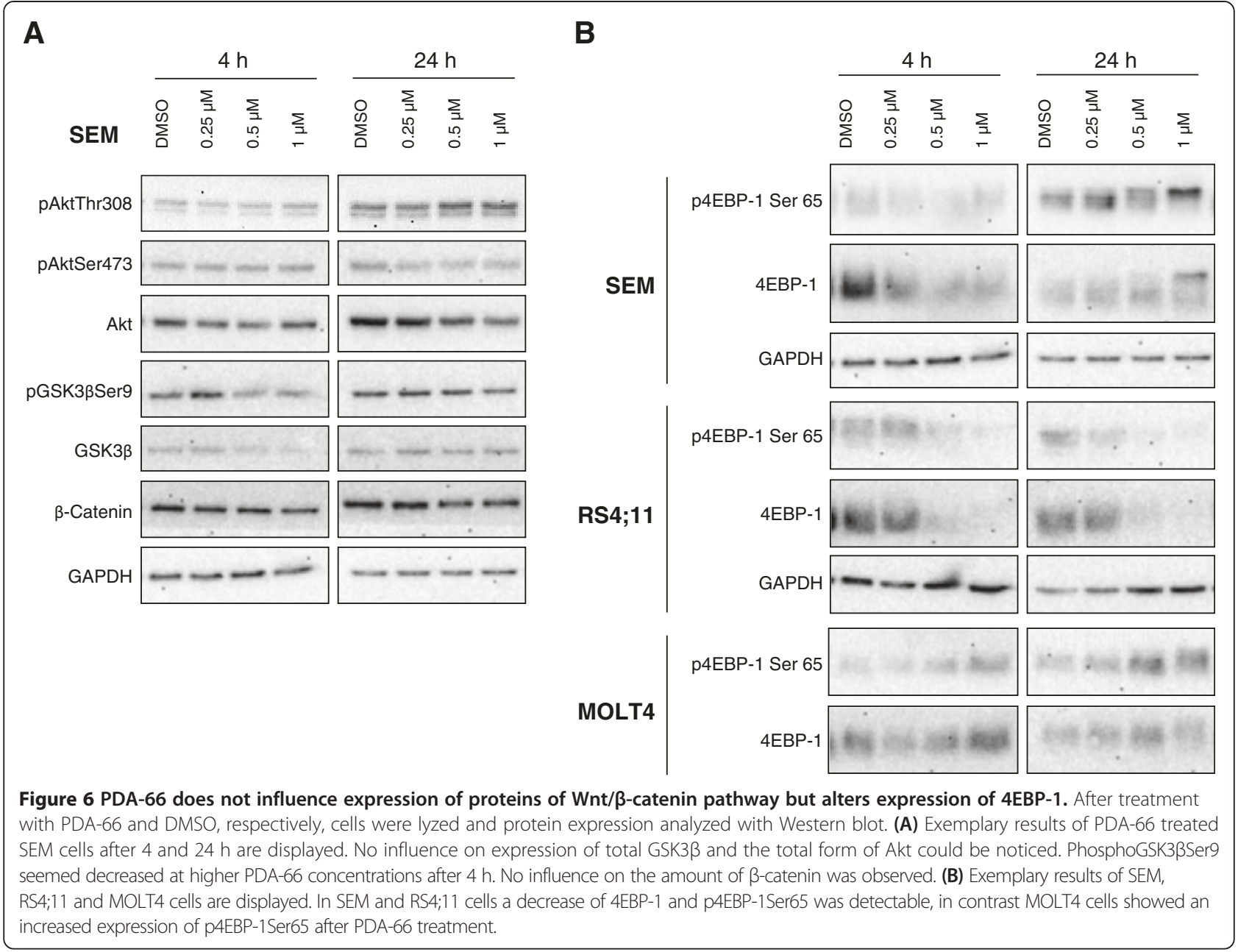

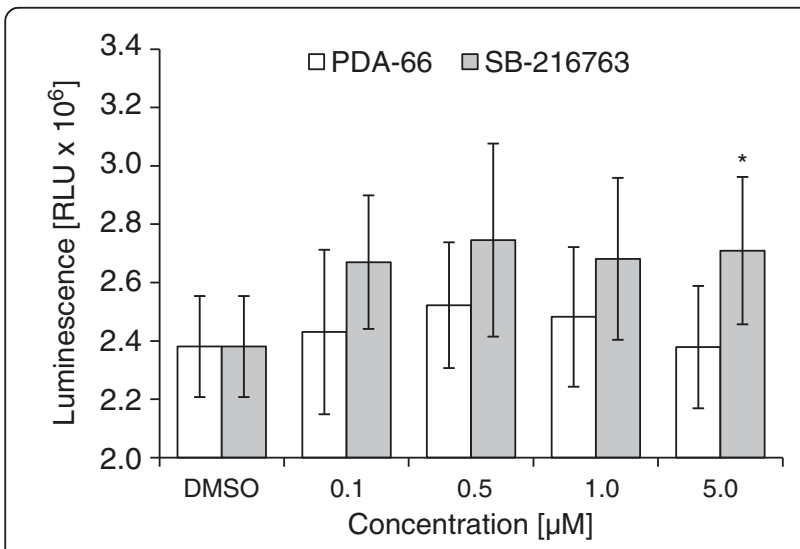

Figure 7 PDA-66 does not inhibit GSK3 $\beta$ kinase activity.

Recombinant human GSK3 3 was incubated with pGS2, ATP and different concentrations of PDA-66 and SB-216763. While treatment with the known GSK3 $\beta$ inhibitor SB-216763 lead to a stable reduction of enzyme activity with significant alterations at 5 MM PDA-66 showed only a slight inhibitory potential. Results are displayed as the mean \pm SD of five independent experiments. In each experiment the concentrations of PDA-66 and the control were tested with 4 replicates. RLU = relative luminescence units. *Significant treatment effect vs. DMSO control, $a=0.05$. 2-methylindole group and a methylated maleimide group. Additionally, the 2,4-dichloro substitution pattern is replaced with a 4-acetyl group in PDA-66. These structural changes are supposed to be key in the reduced capacity of PDA-66 to inhibit GSK3ß.

The influence of PDA-66 on GSK3 $\beta$ activity including other key enzymes of Wnt/ $\beta$-catenin and PI3K/Akt signaling pathways was also investigated by western blot. Affirming the results obtained by kinase activity assay, we found no enhanced activation of the Wnt/ $\beta$-catenin pathway. Considering the role of GSK3 $\beta$ in Wnt signaling an increase of $\beta$-catenin would have been expected when inhibiting GSK3 $\beta$. Furthermore, no effect on the protein expression of GSK3 $\beta$ and no distinct activation of Akt were detectable. In the PI3K/Akt signaling pathway GSK3 $\beta$ acts downstream of Akt [18], although Takada et al. demonstrated that the TNF induced activity of Akt is dependent on GSK3 $\beta$ [19], indicating a possible feedback loop. In the herein analyzed SEM cells a slight increase in pAktThr308 could be observed. However, there was no detectable increase in pAktSer473, which is primarily responsible for activation of Akt [20]. 
Interestingly, PDA-66 influenced the phosphorylation status and the total amount of protein of 4EBP-1 at 4 and $24 \mathrm{~h}$ after treatment. 4EBP-1 is a downstream target of mTOR, which is inhibited by GSK3 $\beta$ via phosphorylation of TSC2 [21]. The phosphorylation and concomitant inactivation of 4EBP-1 by mTOR leads to disaggregation of 4EBP-1 from eIF4F, a translation initiation factor [22]. Walsh and Mohr demonstrated that the phosphorylation of 4EBP-1 leads to its proteasomal degradation [23]. In our study the effect of PDA-66 on the amount of 4EBP-1 was ambiguous. SEM, RS4;11 and Jurkat cells displayed a reduced expression whereas MOLT4 cells showed an enhanced amount of 4EBP-1 protein. A decreased level of protein can be caused by enhanced degradation or reduced transcription and translation, respectively. The expression of 4EBP-1 was shown to be positively regulated by transcription factor ATF-4, which is activated by JNK signaling in murine pancreatic beta-cells [24]. Furthermore, JNK is a mitogen activated protein kinase and therefore member of a complex cascade [25]. An effect of PDA-66 on one of these proteins might also influence the activation of ATF-4 and hence 4EBP-1 expression. Nevertheless, there is a probable influence of PDA-66 on other enzymes and cascades.

Although there was no influence on GSK3 $\beta$ detectable, we hypothesized that the application of PDA-66 could nevertheless induce comparable antiproliferative effects in ALL cancer cells as SB-216763 due to the similar basic molecular structure. Notably, PDA-66 treated ALL cells showed a significant decrease in cell count and metabolic activity which was more distinct than results obtained in standard reference experiments with SB216763 (data not shown). Furthermore the treatment with PDA-66 led to morphological changes like condensation of chromatin and karyorrhexis which can be attributed to the detected induction of apoptosis as well as cell cycle alterations.

Our studies indicate different influences on cell cycle in the analyzed ALL cell lines after $48 \mathrm{~h}$ incubation with PDA-66. Concentrations of 0.25 and $0.5 \mu \mathrm{M}$ PDA-66 led to an increase of cells in the G0/G1 phase whereas treatment with $1 \mu \mathrm{M}$ was followed by decrease of G0/G1 phase and a significant increase in G2 phase in RS4;11 and MOLT4 cells. Jurkat cells also showed a decreasing amount of cells in G0/G1 phase, whereas an increase was detected in SEM cells after incubation with $0.5 \mu \mathrm{M}$ PDA-66. In a previous joint study presented by Eisenlöffel et al. it could be displayed that PDA-66 treatment at comparable concentrations as used in these analyses leads to mitotic arrest in the G2/M phase in hNPCs [15]. This effect on cell cycle was caused by inhibition of microtubule polymerization [15]. Treatment of hNPCs with PDA-66 also led to an attenuated proliferation and an increased rate of apoptosis [15]. An antiproliferative effect was also demonstrated in human cell lines of lung cancer and glioblastoma [15]. Similar results were obtained in our study. The analyzed ALL cells showed a significant increase of apoptosis $48 \mathrm{~h}$ after treatment with PDA-66.

\section{Conclusion}

We demonstrated for the first time a significant and pronounced antiproliferative influence of PDA-66 on ALL cells. In addition, we showed an induction of apoptosis via cleavage of caspases as well as suppression of metabolic activity. While there was an effect on cell cycle progression, no influence on the Wnt/ $\beta$-catenin signaling pathway was observed. The investigation of enzyme activity of GSK3 $\beta$ showed a minor inhibitory effect compared to the analogue substance SB-216763. Nevertheless, the herein observed anti-tumoral potential in ALL and the previous seen effects in neoplastic tissues classify PDA-66 as a promising novel therapeutic agent candidate. Consequently, the detailed analyses of PDA66 mediated effects should be further elucidated and validated in vivo as a base for a perspective therapeutic consideration.

\section{Abbreviations}

4EBP-1: Eukaryotic initiation factor 4E binding protein-1; ALL: Acute lymphoblastic leukemia; ATF-4: Activating transcription factor 4; DMSO: Dimethyl sulfoxide; GSK3 $\beta$ : Glycogen synthase kinase 3 $\beta$; hNPCs: Human neuronal progenitor cells; IC50: Half maximal inhibitory concentration; JNK: C-Jun N-terminal kinase; PARP: Poly (ADP)-ribose polymerase; pGS2: Phospho glycogen synthase peptide 2; PI3K: Phosphatidylinositole 3 kinase; TNF: Tumor necrosis factor.

\section{Competing interests}

The authors declare that they have no competing interests.

\section{Authors' contributions}

CK performed all experiments, participated in study design, partial data analysis and interpretation, partial manuscript drafting. CR performed all experiments, participated in study design, partial data analysis and interpretation, partial manuscript drafting. TSL helped carrying out western blot experiments. AS helped carrying out cell cultivation, proliferation studies and analyses of apoptosis, necrosis and cell cycle. APD developed new substance PDA-66 and partial manuscript editing. MB developed new substance PDA-66 and partial manuscript editing. MJF participated in drug development, partial manuscript editing. CE participated in drug development partial manuscript editing. AR participated in drug development and partial manuscript editing. CJ principal study design, participated in the design of the paper and finalization. All authors read and approved the final manuscript.

\section{Acknowledgements}

TSL was supported by a scholarship of the German federal state Mecklenburg-Vorpommern. Furthermore, we thank Hugo Murua Escobar (University of Rostock, Division of Medicine, Department of Hematology/ Oncology/Palliative Medicine; Small Animal Clinic, University of Veterinary Medicine Hannover, Germany) for the critical revision of the manuscript.

\section{Author details}

${ }^{1}$ Department of Hematology/Oncology/Palliative Medicine, Division of Medicine, University of Rostock, Ernst-Heydemann-Str. 6, Rostock 18057, Germany. ${ }^{2}$ Leibniz-Institute for Catalysis at the University of Rostock, Albert-Einstein-Str. 29a, Rostock 18059, Germany. ${ }^{3}$ Albrecht-Kossel-Institute for Neuroregeneration (Akos), Center for Mental Health, University of Rostock, Gehlsheimerstr. 20, Rostock 18147, Germany. ${ }^{4}$ Centogene AG, Schillingallee 68, Rostock 18057, Germany. 
Received: 16 August 2013 Accepted: 2 February 2014

Published: 6 February 2014

\section{References}

1. Gokbuget N, Hoelzer D: Treatment of adult acute lymphoblastic leukemia. Semin Hematol 2009, 46:64-75.

2. Thomas DA, Faderl S, O'Brien S, Bueso-Ramos C, Cortes J, Garcia-Manero G, Giles FJ, Verstovsek S, Wierda WG, Pierce SA, Shan J, Brandt M, Hagemeister FB, Keating MJ, Cabanillas F, Kantarjian H: Chemoimmunotherapy with hyperCVAD plus rituximab for the treatment of adult Burkitt and Burkitt-type lymphoma or acute lymphoblastic leukemia. Cancer 2006, 106:1569-1580.

3. Ottmann OG, Wassmann B, Pfeifer H, Giagounidis A, Stelljes M, Duhrsen U, Schmalzing M, Wunderle L, Binckebanck A, Hoelzer D: Imatinib compared with chemotherapy as front-line treatment of elderly patients with Philadelphia chromosome-positive acute lymphoblastic leukemia (Ph + ALL). Cancer 2007, 109:2068-2076.

4. Vignetti M, Fazi P, Cimino G, Martinelli G, Di Raimondo F, Ferrara F, Meloni G, Ambrosetti A, Quarta G, Pagano L, Rege-Cambrin G, Elia L, Bertieri R, Annino L, Foa R, Baccarani M, Mandelli F: Imatinib plus steroids induces complete remissions and prolonged survival in elderly Philadelphia chromosome-positive patients with acute lymphoblastic leukemia without additional chemotherapy: results of the Gruppo Italiano Malattie Ematologiche dell'Ad. Blood 2007, 109:3676-3678.

5. Pews-Davtyan A, Tillack A, Ortinau S, Rolfs A, Beller M: Efficient palladiumcatalyzed synthesis of 3-aryl-4-indolylmaleimides. Org Biomol Chem 2008, 6:992-997.

6. Coghlan MP, Culbert AA, Cross DA, Corcoran SL, Yates JW, Pearce NJ, Rausch OL, Murphy GJ, Carter PS, Roxbee Cox L, Mills D, Brown MJ, Haigh D, Ward RW, Smith DG, Murra K, Reith AD, Holder JC: Selective small molecule inhibitors of glycogen synthase kinase-3 modulate glycogen metabolism and gene transcription. Chem Biol 2000, 7:793-803.

7. Kockeritz L, Doble B, Patel S, Woodgett JR: Glycogen synthase kinase-3-an overview of an over-achieving protein kinase. Current drug targets 2006, 7:1377-1388.

8. Korur S, Huber RM, Sivasankaran B, Petrich M, Morin PJ, Hemmings BA, Merlo A, Lino MM: GSK3beta regulates differentiation and growth arrest in glioblastoma. PloS One 2009, 4:e7443.

9. Mai W, Kawakami K, Shakoori A, Kyo S, Miyashita K, Yokoi K, Jin M, Shimasaki T, Motoo Y, Minamoto T: Deregulated GSK3beta sustains gastrointestinal cancer cells survival by modulating human telomerase reverse transcriptase and telomerase. Clin Canc Res 2009, 15:6810-6819.

10. Ghosh JC, Altieri DC: Activation of p53-dependent apoptosis by acute ablation of glycogen synthase kinase-3beta in colorectal cancer cells. Clin Canc Res 2005, 11:4580-4588.

11. Cao Q, Lu X, Feng Y: Glycogen synthase kinase-3beta positively regulates the proliferation of human ovarian cancer cells. Cell Res 2006, 16:671-677.

12. Kunnimalaiyaan $M$, Vaccaro $A M$, Ndiaye MA, Chen H: Inactivation of glycogen synthase kinase-3beta, a downstream target of the raf-1 pathway, is associated with growth suppression in medullary thyroid cancer cells. Mol Cancer Ther 2007, 6:1151-1158.

13. Ougolkov AV, Fernandez-Zapico ME, Savoy DN, Urrutia RA, Billadeau DD: Glycogen synthase kinase-3beta participates in nuclear factor kappaBmediated gene transcription and cell survival in pancreatic cancer cells. Cancer research 2005, 65:2076-2081.

14. Hu Y, Gu X, Li R, Luo Q, Xu Y: Glycogen synthase kinase-3beta inhibition induces nuclear factor-kappaB-mediated apoptosis in pediatric acute lymphocyte leukemia cells. J Exp Clin Cancer Res 2010, 29:154.

15. Eisenlöffel C, Schmöle AC, Pews-Davtyan A, Brennführer A, Kuznetsov SA, Hübner R, Frech S, Schult C, Junghanss C, Beller M, Rolfs A, Frech MJ: Interference of a novel indolylmaleimide with microtubules induces mitotic arrest and apoptosis in human progenitor and cancer cells. Biochem Pharmacol 2013, 85(6):763-771.

16. Schult C, Dahlhaus M, Ruck S, Sawitzky M, Amoroso F, Lange S, Etro D, Glass A, Fuellen G, Boldt S, Wolkenhauer O, Neri LM, Freund M, Junghanss C: The multikinase inhibitor Sorafenib displays significant antiproliferative effects and induces apoptosis via caspase 3, 7 and PARP in B- and T-lymphoblastic cells. BMC Cancer 2010, 10:560.

17. Schmole A, Brennfuhrer A, Karapetyan G, Jaster R, Pews-Davtyan A, Hubner R, Ortinau S, Beller M, Rolfs A, Frech MJ: Novel indolylmaleimide acts as GSK-3beta inhibitor in human neural progenitor cells. Bioorg Med Chem 2010, 18:6785-6795.
18. Vivanco I, Sawyers CL: The phosphatidylinositol 3-Kinase AKT pathway in human cancer. Nat Rev Cancer 2002, 2:489-501.

19. Takada Y, Fang X, Jamaluddin MS, Boyd DD, Aggarwal BB: Genetic deletion of glycogen synthase kinase-3beta abrogates activation of IkappaBalpha kinase, JNK, Akt, and p44/p42 MAPK but potentiates apoptosis induced by tumor necrosis factor. J Biol Chem 2004, 279:39541-39554.

20. Park S, Chapuis N, Tamburini J, Bardet V, Cornillet-Lefebvre P, Willems L, Green A, Mayeux P, Lacombe C, Bouscary D: Role of the PI3K/AKT and mTOR signaling pathways in acute myeloid leukemia. Haematologica 2010, 95:819-828.

21. Inoki K, Ouyang H, Zhu T, Lindvall C, Wang Y, Zhang X, Yang Q, Bennett C, Harada Y, Stankunas K, Wang C, He X, MacDougald OA, You M, Williams BO, Guan K: TSC2 integrates Wnt and energy signals via a coordinated phosphorylation by AMPK and GSK3 to regulate cell growth. Cell 2006, 126:955-968.

22. Morley SJ, Coldwell MJ, Clemens MJ: Initiation factor modifications in the preapoptotic phase. Cell Death Differ 2005, 12:571-584.

23. Walsh D, Mohr I: Phosphorylation of elF4E by Mnk-1 enhances HSV-1 translation and replication in quiescent cells. Gene Dev 2004, 18:660-672.

24. Tominaga R, Yamaguchi S, Satake C, Usui M, Tanji Y, Kondo K, Katagiri H, Koa $Y$, Ishihara H: The JNK pathway modulates expression and phosphorylation of 4E-BP1 in MIN6 pancreatic beta-cells under oxidative stress conditions. Cell Biochem Funct 2010, 28:387-393.

25. Saadeddin A, Babaei-Jadidi R, Spencer-Dene B, Nateri AS: The links between transcription, beta-catenin/JNK signaling, and carcinogenesis. Mol Cancer Res 2009, 7:1189-1196.

doi:10.1186/1471-2407-14-71

Cite this article as: Kretzschmar et al:: The novel arylindolylmaleimide PDA-66 displays pronounced antiproliferative effects in acute lymphoblastic leukemia cells. BMC Cancer 2014 14:71.

\section{Submit your next manuscript to BioMed Central and take full advantage of:}

- Convenient online submission

- Thorough peer review

- No space constraints or color figure charges

- Immediate publication on acceptance

- Inclusion in PubMed, CAS, Scopus and Google Scholar

- Research which is freely available for redistribution

Submit your manuscript at www.biomedcentral.com/submit
C Biomed Central 